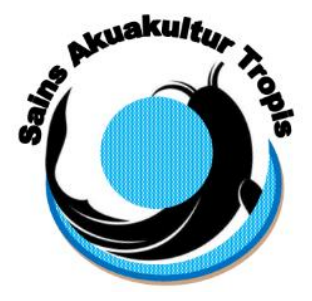

\author{
Jurnal Sains Akuakultur Tropis \\ Departemen Akuakultur \\ Fakultas Perikanan dan IImu Kelautan - Universitas Diponegoro \\ JI. Prof. Soedarto, SH, Tembalang, Semarang 50275 \\ Telp. (024) 7474698, Fax.: (024) 7474698 \\ Email: sainsakuakulturtropis@gmail.com, sainsakuakulturtropis@undip.ac.id
}

\title{
PRODUKSI PEMBENIHAN LELE DUMBO (Clarias gariepinus) STRAIN MUTIARA DAN PAYTON DENGAN PAKAN ALAMI CACING SUTERA DARI KULTUR YANG MEMANFAATKAN LIMBAH PERTANIAN
}

\author{
Seedling Production of African Catfish (Clarias gariepinus) Mutiara and Payton Strains with Live Food of \\ Silkworm Cultured By Using Agricultural Waste Products \\ Suminto*, Titik Susilowati, Sarjito, Diana Chilmawati \\ Departemen Akuakultur, \\ Fakultas Perikanan dan Ilmu Kelautan, \\ Jl. Prof. Soedarto, SH, Tembalang, Semarang, Jawa Tengah -50275, Telp/Fax. +62247474698 \\ * Corresponding author: suminto57@gmail.com
}

\begin{abstract}
ABSTRAK
Ikan lele dumbo (C. gariepinus) merupakan salah satu ikan konsumsi air tawar yang banyak digemari oleh masyarakat Indonesia. Jenis ikan lele strain mutiara dan payton, sebagai hasil pemuliaan ikan yang dikembangkan untuk memproduksi benih unggul guna memenuhi kebutuhan pasar. Peningkatan produksi benih lele, baik strain mutiara maupun payton, dapat menggunakan pakan alami, cacing sutera yang dikultur dengan media limbah pertanian untuk mengurangi biaya produksi. Tujuan penelitian ini adalah untuk mengetahui dan membandingkan produksi benih ikan lele dari strain mutiara dan payton dengan pemberian pakan alami berupa cacing sutera yang dikultur menggunakan limbah pertanian. Penelitian ini menggunakan metode eksperimental, rancangan acak lengkap (RAL) dengan 2 perlakuan 5 kali ulangan. Ikan uji yang digunakan yaitu induk lele dumbo strain mutiara (rerata bobot betina $2.6 \pm 0.3 \mathrm{~kg}$ dan bobot jantan $1.5 \pm 0.1 \mathrm{~kg}$ ) dan strain payton (rerata bobot betina $2.4 \pm 0.5 \mathrm{~kg}$ dan bobot jantan $1.2 \pm 0.2$ $\mathrm{kg}$ ). Perlakuan yang digunakan yaitu perlakuan A (strain mutiara) dan perlakuan B (strain payton). Variabel data yang diukur meliputi data produksi diantaranya jumlah telur (butir), HR (\%) dan jumlah (ekor). Data lain yaitu TKP, FCR, RGR dan SR. Kualitas air pada media pemeliharaan tergolong dalam kisaran yang layak untuk pemeliharaan. Hasil penelitian menunjukkan produksi telur strain mutiara $94510 \pm 1423.7$ butir dan strain payton $93010 \pm 1970.3$ butir. Nilai HR strain mutiara $85.35 \pm 0.51 \%$ dan strain payton $84.02 \pm 1.29 \%$. Jumlah yang dihasilakan induk strain mutiara $81064.8 \pm 1034.3$ ekor dan strain payton $78595.6 \pm 2400.3$ ekor. Hasil TKP strain mutiara sebesar $7.92 \pm 0.51$ gr/ind dan payton $5.53 \pm 0.52 \mathrm{gr} / \mathrm{ind}$. Nilai FCR lele mutiara sebesar $1.15 \pm 0.00$ dan lele payton $1.25 \pm 0.00$. Nilai RGR benih lele mutira sebesar $7.1 \pm 0.00 \%$ dan strain lele payton sebesar $6.9 \pm 0.00 \%$ dan nilai SR benih lele mutiara $85.00 \pm 0.00 \%$ dan benih lele payton sebesar $80.00 \pm 0.00 \%$.
\end{abstract}

Kata kunci: Strain Lele, Mutiara, Payton, Cacing Sutera, Produksi

\begin{abstract}
African catfish (C. gariepinus) is one of the freshwater consumption fish that is much favored by the people of Indonesia. Mutiara and Payton strains, as a result of breeding, have begun to be developed to fulfill of demand. Increased production of catfish can be done by using live food of silkworms cultured in the media from agricultural waste so as to reduce production costs. The purpose of this study was to determine the production lof catfish from the strains of mutiaras and payton by feeding a type of natural food in the form of silkworms cultured using agricultural waste. This study used an experimental method, a completely randomized design (CRD) with 2 treatments 5
\end{abstract}


replications. The test fish used were the mother of mutiara strains of African catfish (mean female weight $2.6 \pm 0.3 \mathrm{~kg}$ and male weight $1.5 \pm 0.1 \mathrm{~kg}$ ) and payton strain (mean weight of females $2.4 \pm 0.5 \mathrm{~kg}$ and male weight $1 . \pm 0.2 \mathrm{~kg}$ ). The treatments used were treatment A (mutiara strain) and treatment B (Payton strain). The variables include scene on seed production including number of eggs (grains), HR (\%) and number of e (tails). Other data are FCR, RGR and $S R$. Water quality in maintenance media is in the appropriate range for maintenance. The results showed fecundity of mutiara strain $94510 \pm 1423.7$ grains and payton strain $93010 \pm 1970.3$ grains. The HR value of mutiara strain was $85.35 \pm 0.51 \%$ and payton strain was $84.02 \pm 1.29 \%$. The number of e produced by the broodstocks of mutiara strain was $81064.8 \pm 1034.3$ tails and strain Payton was $78595.6 \pm 2400.3$ tails. The results of the TKP mutiara strain were $7.92 \pm 0.51 \mathrm{gr} /$ ind and payton $5.53 \pm 0.52 \mathrm{gr} /$ ind. The FCR value of mutiara catfish seeds is $1.15 \pm 0.00$ and payton strain is $1.25 \pm 0.00$. The value of RGR of mutira strain was $7.1 \pm 0.00 \%$ and the payton strain was $6.9 \pm 0.00 \%$ and the $S R$ value of mutiara strain was $85.00 \pm 0.00 \%$ and payton strain were $80.00 \pm 0.00 \%$.

Keywords: Catfish strains, Mutiara, Payton, Silkworm, Production.

Article Received: 19-01-2019; Accepted: 28-01-2019

\section{PENDAHULUAN}

Kebutuhan lele dumbo (Clarias gariepinus) dari tahun ke tahun semakin meningkat, seiring dengan bertambahnya jumlah penduduk. Pencapaian produksi yang belum memenuhi kebutuhan pasar, sehingga perlu diadakannya pemuliaan benih ikan melalui penggunaan benih dari hasil rekayasa genetika. Jenis ikan lele yang biasa dibudidayakan di Indonesia ialah dari jenis ikan lele lokal, "Lele Dumbo". Jenis ikan lele tersebut sudah dilakukan rekayasa genetika sehingga dapat dihasilkan strain baru yaitu strain mutiara dan payton. Pada dasarnya, ikan lele strain mutiara dan payton tidak jauh berbeda dengan ikan lele dumbo. Strain baru dari lele dumbo strain mutiara dan payton sebagai hasil pemuliaan mulai dikembangkan produksi benihnya oleh pembudidaya guna memenuhi konsumsi pasar.

Keunggulan dalam teknologi budidaya ikan lele yang mudah diterapkan, padat tebar yang tinggi serta ketahanan hidup terhadap kondisi lingkungan yang tinggi menyebabkan ikan lele menjadi komoditas utama bagi pembudidaya ikan air tawar, terlebih kini muncul adanya strain Mutiara dan Payton. Keberhasilan dalam kegiatan budidaya tidak telepas dari yang sehat dan penyediaan pakan yang cukup. cenderung rentan terhadap kematian, sehingga diperlukan penyediaan pakan hidup yang sesuai dengan kebutuhan nutrisinya. Saat ini, belum ada jenis pakan buatan yang dapat menggantikan jenis pakan alami yang biasa digunakan sebagai pakan awal bagi, terlebih saat kuning telur mulai habis. Oleh karenanya diperlukan kegiatan yang menjadi integral untuk keberhasilan kegiatan pembenihan diperlukan penyediaan pakan alami, berupa cacing sutera.

Ketersediaan cacing sutera (Tubifex sp.) sebagai pakan alami utama didalam kultur benih lele sampai saat ini masih berfluktuatif. Pemenuhan kebutuhan pakan alami, cacing sutera untuk pembenihan masih menggunakan dari hasil penangkapan di alam, yang menjadi kendala dalam usaha pembenihan. Hal ini menjadikan diperlukannya upaya kultur dalam lingkungan terkontrol untuk memenuhi kebutuhan selama kegiatan pembenihan (Syaputra et al., 2017).

Cacing sutera (Tubifex sp.) merupakan jenis pakan hidup yang dapat diberikan pada beberapa spesis ikan maupun non ikan. Kandungan nutrisi dari Tubifex sp. terdiri dari 57\% protein, 13,30\% lemak, 2,04\% karbohidrat (Madinawati et al., 2011). Adanya kandungan nutrisi tersebut menjadikan peran dari Tubifex sp. sebagai pakan yang layak bagi pertumbuhan maupun kelangsungan hidup dari ikan lele. Keunggulan dari Tubifex sp. dibandingkan dengan pakan buatan yaitu dari segi ketersediaan, harga yang lebih terjangkau dan mudah terurai di air sehingga kualitas air dapat terjaga dengan baik. Beberapa jenis ikan konsumsi yang sangat menyukai cacing sutra adalah ikan sidat dan ikan lele (Ngatung, et al., 2017).

Ketersediaan cacing sutera yang dapat ditemukan dialam, dapat dijadikan sebagai bibit untuk dikultur pada media. Media kultur bagi cacing sutera dapat berupa limbah pertanian maupun peternakan. Limbah tersebut diantaranya berupa ampas tahu, bungkil jagung dan kotoran sapi. Begum et al. (2014), mengatakan bahwa media yang digunakan selama kultur cacing sutera dapat menentukan biomassa cacing sutera saat dipanen. Penelitian lain terkait media yang dapat digunakan untuk kultur cacing sutera yaitu ddengan memanfaatkan kotoran unggas. Biomassa cacing sutera yang dihasilkan dari hasil kultur dengan media tersebut mampu memenuhi untuk digunakan sebagai pakan bagi ikan hias dan udang (Hamron et al., 2018).

\section{MATERI DAN METODE Kultur Cacing Sutera}

Persiapan bahan pakan yaitu meliputi pembuatan konstruksi rumah cacing sutera yang terdiri dari rak-rak untuk wadah kultur. Tahap selanjutnya yaitu pengolahan limbah pertanian yang akan digunakan sebagai media kultur. 
Wadah dengan luasan 7,2 $\mathrm{m}^{2}$ sebanyak 4 rak masing-masing diisi dengan media kultur cacing sutera. Media terdiri dari lumpur setinggi $1 \mathrm{~cm}$ dan campuran hasil fermentasi bungkil jagung, ampas tahu serta feses ayam setinggi 2-3 $\mathrm{cm}$ menggunakan EM4 selama 3 hari. Media yang telah tercampur, selanjutnya diratakan ketinggiannya dan dapat diisi dengan air setinggi $1 \mathrm{~cm}$. Sistem pengairan yang diterapkan ialah sistem resirkulasi. Sistem ini menerapkan prinsip dengan penggunaan air yang akan kembali (resirkulasi) pada sistem budidaya. Air dari wadah pemeliharaan cacing sutra yang masuk kedalam filter akan dialirkan kembali menuju wadah pemeliharaan (Warades dan Pindo, 2018). Benih cacing sutera sebanyak $150 \mathrm{~g} / \mathrm{m}^{3}$ kemudian ditebar ke media yang telah disiapkan. Pemeliharaan cacing sutera dilakukan setelah seminggu pemeliharaan dengan menambahkan media secukupnya dengan tujuan untuk memenuhi kndungan bahan organik untuk cacing sutera (Suryadin et al., 2017).

\section{Pemijahan Induk Lele}

Induk lele yang digunakan yaitu strain Mutiara dengan rerata bobot betina $2.6 \pm 0.3 \mathrm{~kg}$ dan rerata bobot jantan $1.5 \pm 0.1 \mathrm{~kg}$ dan strain Payton dengan rerata bobot betina $2.4 \pm 0.5 \mathrm{~kg}$ dan rerata bobot jantan $1.2 \pm 0.2 \mathrm{~kg}$. Induk berasal dari Balai Pembenihan Ikan Air Tawar Ngrajek, Jawa Tengah. Induk ikan lele diletakkan pada wadah yang berbeda antara jantan dan betina dengan ukuran kolam masing2 kolam 4x6 $\mathrm{m}^{2}$ dengan ketinggian air $80 \mathrm{~cm}$ (Ardyanti, et al., 2017).

Persiapan untuk pemijahan induk ikan lele yaitu dengan menyiapkan media pemijahan berupa susunan ijuk didalam kolam yang telah terisi air dan dilengkapi dengan sistem aerasi. Kolam yang telah terisi air setinggi $40-60 \mathrm{~cm}$ siap digunakan sebagai wadah pemijahan. Setiap kolam pemijahan, perbandingan induk yang digunakan yaitu sebanyak 1 jantan dan 2 betina. Induk lele yang terseleksi, selanjutnya ditimbang untuk ditentukan dosis ovaprimnya. Penggunaan ovaprim ditujukan untuk mempercepat keluarnya sel sperma dari induk jantan dan sel telur dari induk betina.

Dosis ovaprim disesuaikan sebanyak $0,4 \mathrm{ml} / \mathrm{kg}$ untuk induk jantan dan $2 \mathrm{ml} / \mathrm{kg}$ untuk induk betina (Wulandari et al., 2017). Penyuntikan dilakukan pada bagian punggung induk ikan lele. Usai 12 jam penyuntikan, induk akan memijah. Induk ikan lele yang telah memijah mengeluarkan telur yang menempel pada media kakaban, selanjutnya dipisahkan (Nzeh and Obaroh, 2012).

\section{Kultur Ikan Lele}

Telur yang menetas akan menjadi yang dalam waktu 1-3 hari tidak memerlukan makanan. Jumlah benih yang ditebar untuk tiap perlakuan dan ulangan sebanyak 1 ekor/ liter. Ukuran kolam terpal yang digunakan untuk pemeliharaan ikan lele masing-masing perlakuan ialah sebesar 3 x 4 × $1 \mathrm{~m}$ dengan kedalaman air $35-40 \mathrm{~cm}$ dan padat tebar $2500 \mathrm{ekor} / \mathrm{m}^{2}$ luas kolam pemeliharaan. (Kerneta, 2014). dipelihara dalam kolam pemeliharaan dari D1-D45

\section{Pemberian Pakan}

Pemberian pakan pada penelitian ini diberikan secara fix feeding rate dengan catatan 2-15 hari pertama menggunakan pakan alami jenis cacing sutera dari hasil kultur, 16-30 hari berikutnya menggunakan pakan buatan sebanyak 16\% dari bobot biomassa kemudian 31-45 hari berikutnya pakan yang diberikan dihitung sebanyak $14 \%$ dari bobot biomassa.

Metode penelitian yang digunakan adalah metode eksperimental. Menurut Ghozali (2006), metode eksperimen yang dapat dilakukan untuk mengungkap fakta baru atau menguatkan teori bahkan membantah penelitian-penelitian yang sudah ada. Rancangan percobaan yang digunakan dalam penelitian adalah rancangan acak lengkap (RAL) menggunakan 2 perlakuan dan dengan 3 kali ulangan, susunan perlakuannya adalah sebagai berikut:

Perlakuan A: induk strain mutiara

Perlakuan B: induk strain payton

Pengumpulan data dilakukan dengan metode observasi. Variabel yang diamati meliputi nilai bobot induk, jumlah telur, Hatching Rate, dan jumlah sedangkan untuk variabel lain meliputi total konsumsi pakan (TKP), rasio konversi pakan (FCR), laju pertumbuhan relatif (RGR), kelulushidupan (SR) serta kualitas air yang meliputi DO, pH, suhu dan amonia.

Variabel yang diamati adalah:

\section{Nilai Bobot Induk}

Bobot induk ikan lele dapat dihitung dengan melakukan penimbangan pada masing-masing induk, baik jantan maupun betina.

\section{Jumlah Telur}

Telur yang dihasilkan oleh induk dapat diketahui dengan menghitung jumlah telur per satuan volume sampel (Efrizal, 1998). Jumlah telur yang keluar bergantung pada banyaknya telur yang sudah matang. Hal ini dipengaruhi oleh penggunaan hormon guna pematangan oosit (Sukendi, 2007). 


\section{HR (Hatching Rate)}

Daya tetas (HR/Hatching Rate) dapat diketahui dengan menghitung telur yang menetas pada masing-masing perlakuan. Menurut Efrizal (1998), daya tetas dapat dihitung dengan persamaan :

\section{Jumlah Benih}

$$
\operatorname{HR}(\%)=\frac{\text { Jumlah telur menetas }}{\text { Jumlah telur sampel }} \times 100 \%
$$

Jumlah benih dihitung berdasarkan jumlah telur yang berhasil menetas dalam satuan ekor, dan dapat diketahui dengan cara menghitung jumlah ekor per satuan volume (Efrizal, 1998).

\section{Total Konsumsi Pakan}

Perhitungan nilai tingkat konsumsi pakan dihitung dengan menggunakan rumus Pereira et al., (2007) sebagai berikut:

$$
\mathrm{TKP}=\mathrm{F} 1-\mathrm{F} 2
$$

TKP yaitu Total konsumsi pakan (g), F1 yaitu jumlah pakan awal (g), F2 yaitu jumlah pakan akhir (g)

\section{Rasio Konversi Pakan (FCR)}

Perhitungan nilai rasio konversi pakan (FCR) dihitung dengan menggunakan rumus Stickney (1979) sebagai berikut:

$$
\mathrm{FCR}=\frac{\sum \text { Pakan }}{\Delta \text { Biomassa }}
$$

Dimana FCR yaitu rasio konversi pakan, $\sum$ Pakan yaitu jumlah pakan yang diberikan selama penelitian $(\mathrm{g}), \Delta$ Biomassa yaitu selisih biomassa awal penelitian dan akhir penelitian (g).

\section{Laju Pertumbuhan Relatif (RGR)}

Menurut Jauncey (1998), laju pertumbuhan relatif atau relative growth rate (RGR) ikan dihitung menggunakan rumus sebagai berikut:

$$
\mathrm{RGR}=\frac{\mathrm{W}_{\mathrm{t}}-\mathrm{W}_{0}}{\mathrm{~W}_{0} \times \mathrm{t}} \times 100 \%
$$

RGR yaitu Laju pertumbuhan relatif (\% per hari), $\mathrm{W}_{\mathrm{t}}$ yaitu bobot total ikan pada akhir pemeliharaan ( $\left.\mathrm{g}\right), \mathrm{W}_{\mathrm{o}}$ yaitu bobot total benih ikan pada awal pemeliharaan $(\mathrm{g}), \mathrm{t}$ yaitu waktu pemeliharaan (hari)

\section{Kelulushidupan}

Kelulushidupan atau survival rate (SR) dihitung untuk mengetahui tingkat kematian kematian ikan uji selama penelitian. Menurut Murtidjo (2001), kelulushidupan dapat dihitung menggunakan rumus :

$$
\mathrm{SR}=\frac{\mathrm{N}_{\mathrm{t}}}{\mathrm{N}_{0}} \times 100 \%
$$

SR yaitu Tingkat kelulushidupan ikan (\%), $\mathrm{N}_{\mathrm{t}}$ yaitu jumlah ikan pada akhir penelitian (ekor), $\mathrm{N}_{0}$ yaitu jumlah ikan pada awal penelitian (ekor)

\section{Parameter Kualitas Air}

Parameter data kualitas air yang diukur meliputi DO, pH, suhu dan amonia. DO diukur dengan menggunakan DO meter, $\mathrm{pH}$ diukur dengan $\mathrm{pH}$ meter, suhu diukur dengan termometer dan untuk pengukuran amonia, sampel air diukur di laboratorium teknik lingkungan, UNDIP dengan menggunakan metode spektofotometri

\section{Analisis Data}

Analisa data meliputi tingkat konsumsi pakan (TKP), rasio konversi pakan (FCR), laju pertumbuhan relative (RGR), kelulushidupan (SR) dan kualitas air. Variabel yang didapatkan kemudian dianalisis menggunakan uji t (ttest). selang kepercayaan 95\%, sebelum dilakukan uji t ( $t$-test), data terlebih dahulu dilakukan uji normalitas, uji homogenitas, dan uji addivitas guna mengetahui bahwa data bersifat normal, homogen dan aditif untuk dilakukan uji lebih lanjut yaitu uji t ( $t$-test) (Ghozali 2006). Data kualitas air dianalisis secara deskriptif.

\section{HASIL}

Hasil data pemijahan lele dumbo (C. garipienus) strain mutiara dan payton meliputi nilai bobot induk, jumlah telur, Hatching Rate, dan jumlah tersaji pada Tabel 1. 
Tabel 1. Rerata Bobot Induk, Jumlah Telur, HR, dan Jumlah Benih yang Dihasilkan dari Induk Lele Strain Mutiara dan Payton.

\begin{tabular}{lcc}
\hline No Variabel & Lele Mutiara & Lele Payton \\
\hline 1. & & \\
Bobot Induk & & \\
Jantan (kg) & $2.56 \pm 0.44^{\mathrm{a}}$ & $2.47 \pm 0.51^{\mathrm{a}}$ \\
2.tina (kg) Jumlah telur (butir) & $1.41 \pm 0.22^{\mathrm{a}}$ & $1.22 \pm 0.220^{\mathrm{a}}$ \\
3. HR (\%) & $94510 \pm 1423.7^{\mathrm{a}}$ & $93010 \pm 1970.3^{\mathrm{a}}$ \\
4. Jumlah benih (ekor) & $85.35 \pm 0.51^{\mathrm{a}}$ & $84.02 \pm 1.29^{\mathrm{a}}$ \\
\hline
\end{tabular}

Keterangan: Nilai rerata dengan huruf superscript yang sama menunjukkan antar perlakuan tidak berbeda nyata $(\mathrm{P}>0.05)$.

Hasil penelitian produksi benih lele dumbo (C. gariepinus) strain mutiara dan payton meliputi nilai TKP;FCR; RGR; dan SR tersaji pada Tabel 2.

Tabel 2. Nilai Rata-rata TKP, RGR, dan SR Benih Lele selama Pemeliharaan

\begin{tabular}{llcc}
\hline No. & \multicolumn{1}{c}{ Variabel } & Lele Mutiara & Lele Payton \\
\hline 1. & TKP (g/ind) & $7,92 \pm 0,51^{\mathrm{a}}$ & $5,53 \pm 0,52^{\mathrm{b}}$ \\
2. & FCR & $1,15 \pm 0,00^{\mathrm{a}}$ & $1,25 \pm 0,00^{\mathrm{b}}$ \\
3. & RGR $(\%)$ & $7,1 \pm 0,00^{\mathrm{a}}$ & $6,9 \pm 0,00^{\mathrm{b}}$ \\
4. & SR $(\%)$ & $85,00 \pm 0,00^{\mathrm{a}}$ & $80,00 \pm 0,00^{\mathrm{b}}$ \\
\hline
\end{tabular}

Keterangan: Nilai rerata dengan huruf superscript yang berbeda menunjukkan adanya perbedaan yang nyata $(\mathrm{P}<0.05)$ dan huruf superscript yang sama menunjukkan tidak berbeda nyata.

Sesuai data hasil pemijahan yang terdapat pada Tabel 1. diketahui nilai bobot induk, jumlah telur, hatching rate (HR) dan jumlah tidak terdapat perbedaan yang nyata. Rata-rata bobot induk jantan dan betina perlakuan A (strain mutiara) adalah $2,56 \pm 0,44 \mathrm{~kg}$ dan $1.41 \pm 0,22 \mathrm{~kg}$. Rata-rata bobot induk jantan dan betina perlakuan B (strain payton) adalah $2,47 \pm 0,51 \mathrm{~kg}$ dan $1,22 \pm 0,220 \mathrm{~kg}$. Rata-rata jumlah telur yang dihasilkan induk perlakuan A (strain mutiara) dan perlakuan B (strain payton) adalah $94510 \pm 1423,7$ butir dan $93010 \pm 1970,3$ butir. Nilai rata-rata HR yang diperoleh dari telur perlakuan A (strain mutiara) dan perlakuan B (strain payton) adalah $85,35 \pm 0,51 \%$ dan $84,02 \pm 1.29 \%$ sedangkan rata-rata jumlah yang diperoleh dari perlakuan A (strain mutiara) dan perlakuan B (strain payton) adalah $81064,8 \pm 1034,3$ ekor dan $78595,6 \pm 2400,3$ ekor.

Data hasil penelitian produksi pembenihan yaitu total konsumsi pakan (TKP), FCR, RGR dan SR antar perlakuan terdapat perbedaan yang nyata, rata-rata TKP benih lele mutiara adalah $7,92 \pm 0,51 \mathrm{~g} / \mathrm{ind}$ dan perlakuan benih lele payton adalah 5,53 $\pm 0,52 \mathrm{~g} / \mathrm{ind}$. Nilai rata-rata FCR benih lele mutiara adalah $1,15 \pm 0,00$ dan benih lele payton sebesar $1,25 \pm 0,00$. Nilai rata-rata laju pertumbuhan relatif (RGR) pada benih lele mutiara adalah $7,1 \pm 0,00 \%$ dan pada benih lele payton adalah $6,9 \pm 0,00 \%$. Nilai rata-rata kelulushidupan (SR) benih lele mutiara adalah $85 \pm 0,00 \%$ dan benih lele payton adalah $80 \pm 0,00 \%$.

Hasil pengukuran parameter kualitas air pada media ikan lele dumbo (C. gariepinus) strain mutiara dan payton selama pemeliharaan tersaji pada Tabel 3.

Tabel 3. Hasil Pengukuran Parameter Kualitas Air selama Pemeliharaan

\begin{tabular}{ccc}
\hline Parameter Kualitas Air & Kisaran Nilai Parameter Kualitas Air & Pustaka (Kelayakan) \\
\hline $\mathrm{Suhu}\left({ }^{0} \mathrm{C}\right)$ & $24-30$ & $22-32^{\mathrm{a}}$ \\
$\mathrm{DO}(\mathrm{mg} / \mathrm{l})$ & $3,3-6,5$ & $>3 \mathrm{mg} / \mathrm{l}^{\mathrm{a}}$ \\
$\mathrm{pH}$ & $6,8-7,1$ & $6,5-8,6^{\mathrm{b}}$ \\
$\mathrm{NH}_{3}(\mathrm{mg} / \mathrm{l})$ & $0-0,31$ & $<1^{\mathrm{a}}$ \\
\hline
\end{tabular}

Keterangan: ${ }^{\mathrm{a} S N I}$ (2015), ${ }^{\mathrm{b}}$ Ahmadi et al., (2012)

Kualitas air pada media pemeliharaan ikan lele dumbo dumbo (C. gariepinus) strain mutiara dan payton pada penelitian ini telah memenuhi kebutuhan hidup ikan lele dumbo. Kualitas air dalam penelitian ini dapat dikatakan layak berdasarkan pustaka tentang kondisi kualitas air yang optimal bagi kehidupan ikan lele dumbo (C. gariepinus). 


\section{PEMBAHASAN}

Berdasarkan data pada Tabel 1, setelah dilakukan uji-t, diperoleh jumlah telur dari induk strain mutiara dan strain payton yang tidak berbeda nyata $(p>0,05)$. Ikan lele strain mutiara memiliki jumlah telur sebanyak 94510 butir sedangkan pada strain paiton sebanyak 93010 butir. Hasil tersebut menunjukkan bahwa induk lele dari strain mutiara menghasilkan jumlah telur yang tidak berbeda jumlahnya dengan yang dihasilkan dari induk strain payton untuk satuan berat yang sama. Nilai fekunditas induk betina pada kedua strain induk tergolong tinggi. Hal ini sesuai dengan (BSN, 2000) yang menyatakan bahwa ikan lele dumbo pada umumnya memiliki nilai fekunditas dengan kisaran 50.000-100.00 butir/kg bobot induk. Sejalan dengan itu, Eyo et al. (2016), menyatakan bahwa fekunditas induk ikan lele tergolong tinggi apabila nilainya mencapai kisaran 68.000-140.000 butir/kg bobot induk.

Nilai hatcing rate pada masing masing perlakuan tidak menunjukkan adanya perbedaan yang nyata. Perlakuan A (strain mutiara) menghasilkan nilai hatcing rate sebesar $83,35 \pm 0,51 \%$ dan pada perlakuan B (strain lele payton) sebesar 84,02 $\pm 1,29 \%$. Menurut Iswanto et al. (2016), derajat penetasan telur ikan lele strain mutiara berkisar 70\%$80 \%$. Semakin sering induk dipijahkan maka derajat penetasanya juga akan semakin menurun. Hal tersebut juga menunjukkan bahwa induk akan mengalami penurunan mutu seiring bertambahnya jumlah waktu pemijahan. Metode pemijahan juga dapat mempengaruhi nilai hatcing rate. Pemijahan yang dilakukan secara alami dengan rentang waktu pemijahan tertentu dapat menghasilkan derajat penetasan yang optimum (lebih dari 70\%).

Jumlah benih yang dihasilkan dari induk strain mutiara yaitu sebanyak 81.064 ekor sedangkan pada strain paiton sebanyak 78.595 ekor. Hasil tersebut tidak adanya perbedaan yang nyata diantara kedua induk. Pada dasarnya jumlah benih yang dihasilkan sejalan dengan nilai HR (derajat penetasan). Oleh karenanya jumlah benih yang dihasilkan apabila mendasarkan nilai HR tergolong memiliki nilai yang tinggi karena dapat mencapai nilai lebih dari $60 \%$. Menurut Gbemisola dan Adebayo (2014), bahwa jumlah yang dihasilkan dari telur yang menetas tergolong tinggi, yaitu mencapai nilai sekitar 60-66\%. Berbeda halnya dengan pendapat Omitoyin et al. (2005), derajat penetasan pada ikan lele yang digunakan dalam pemijahan di Nigeria tergolong tinggi apabila mencapai nilai lebih dari $80 \%$.

Pemanfaatan pakan buatan pada ikan lele mutiara dan payton yang diamati yaitu meliputi TKP. Hasil uji-t menunjukkan bahwa total konsumsi pakan (TKP) memiliki pengaruh yang nyata antar perlakuan. Total konsumsi pakan pada benih lele strain mutiara sebesar 7.56 $\pm 0,51 \mathrm{gr} /$ ind sedangkan benih lele strain payton sebesar 5,55 $\pm 0,52$ gr/ind. Hal ini diduga karena metode pemberian pakan yang diberikan secara at satiation dapat mempengaruhi jumlah pakan yang dikonsumsi oleh ikan. Pakan yang dikonsumsi oleh ikan bisa berbeda beda dikarenakan pada metode ini ikan dalam mengkonsumsi pakan diberikan pada kondisi dan faktor lingkungan. Menurut Abidin et al. (2015), besar kecilnya total konsumsi pakan pada ikan dipengaruhi oleh beberapa faktor, antara lain sifat fisik pakan misalnya bau, rasa, ukuran, dan warna. Faktor lain yang berpengaruh seperti kualitas air misalnya suhu pada suatu perairan. Perairan yang memiliki suhu tinggi akan mempengaruhi proses metabolisme ikan, semakin tinggi suhu akan menyebabkan ikan cenderung mengkonsumi pakan lebih banyak atau proses metabolisme dari ikan akan meningkat.

Kandungan nutrisi yang terkandung pada pakan dapat meningkatkan tingkat konsumsi pakan ikan lele dumbo. Pakan yang mengandung nutrisi yang cukup baik diduga dapat meningkatkan palatabilitas pakan dan tingkat pengambilan pakan oleh ikan. Tingkat konsumsi pakan yang lebih tinggi akan cenderung menghasilkan pertumbuhan yang lebih tinggi dibandingkan jika tingkat konsumsi pakannya lebih sedikit. Menurut Amin (2007), tingkat konsumsi pakan yang lebih tinggi akan cenderung menghasilkan pertumbuhan yang lebih tinggi dibandingkan jika tingkat konsumsi pakannya lebih sedikit. Rendahnya tingkat konsumsi pakan menyebabkan semakin rendahnya kemungkinan ikan untuk memenuhi kebutuhan nutriennya, sehingga mengakibatkan rendahnya pertumbuhan.

Berdasarkan data pada tabel 1, nilai FCR yang diperoleh pada benih ikan lele strain mutiara ialah sebesar 1,15 sedangkan pada benih ikan lele strain pyton sebesar 1,25. Nilai FCR tersebut menunjukkan bahwa pada benih ikan lele strain mutiara dapat menghasilkan biomassa sebesar $1 \mathrm{~kg}$ apabila mengkonsumsi pakan sebanyak $1,15 \mathrm{~kg}$ sedangkan pada benih ikan lele strain pyton memerlukan pakan sebanyak 1,25 kg. Nilai FCR ini dapat menunjukkan efisien tidaknya pakan yang dikonsumsi oleh ikan. Semakin rendah nilai FCR mengindikasikan bahwa pakan yang termakan oleh ikan dapat termanfaatkan untuk pertumbuhan. Hal ini sejalan dengan pendapat Fran dan Akbar (2013) bahwa nilai FCR bukan sepenuhnya angka mutlak. Hal ini dikarenakan bahwa FCR tidak hanya ditentukan oleh kualitas pakan, namun dapat pula dipengaruhi oleh jenis kultivan yang berbeda dan faktor genetika.

Pada dasarnya, nilai FCR tidak hanya ditentukan oleh kualitas pakan. Berbagai faktor selama pemeliharaan benih dapat menentukan besarnya nilai FCR benih ikan lele mutiara maupun pyton. Faktor tersebut diantaranya dari jenis kultivan, ukuran ikan yang dipelihara, padat tebar maupun dari faktor genetik. Berdasarkan data, diperoleh bahwa faktor genetik dari ikan lele strain Mutiara diindikasikan mempengaruhi nilai FCR yang memiliki nilai lebih rendah bila dibandingkan dengan benih lele strain Pyton. Sejalan dengan BPPI (2014), bahwa ikan lele dari strain Mutiara memiliki keunggulan dari segi pertumbuhan maupun efisiensi pakan. 
Berdasarkan hasil analisis uji-t diketahui bahwa nilai RGR berpengaruh nyata antar perlakuan dengan nilai terbaik diperoleh pada perlakuan A (strain mutiara) sebesar 7.1 $\pm 0.00 \%$. sedangkan perlakuan B (strain payton) sebesar $6.9 \pm 0.00 \%$. Menurut Saputra et al. (2013), Jumlah pakan yang mampu dikonsumsi ikan setiap harinya dan tingkat konsumsi makanan harian merupakan salah satu faktor yang mempengaruhi ikan untuk tumbuh secara maksimal. Faktor lain yang mempengaruhi pertumbuhan yaitu efisiensi pemanfaatan pakan. Semakin tinggi efisiensi pakan, maka semakin banyak pula pakan yang dimanfaatkan oleh ikan untuk pertumbuhan. Penelitian Iswanto (2015) menunjukkan bahwa pengujian keragaan-keragaan zooteknis menunjukkan bahwa ikan lele mutiara memiliki keunggulan karakter yang relatif lengkap sebagai komoditas perikanan budidaya, terutama pada karakter pertumbuhan, efisiensi pakan, keseragaman ukuran, dan ketahanan terhadap penyakit, lingkungan, dan stress dibandingkan dengan lele Mesir, Paiton, Sangkuriang, dan Dumbo.

Berdasarkan Uji-t menunjukkan bahwa penambahan nilai kelulushidupan pengaruh nyata $(\mathrm{P}<0,05)$ antar perlakuan. Nilai SR pada perlakuan A yaitu sebesar $85,00 \pm 0,00 \%$ dan pada perlakuan B sebesar $80,00 \pm 0,00 \%$. Tingkat kelulushidupan dapat dipengaruhi oleh penanganan selama yang dapat mempengaruhi tingkat stress dan nafsu makan kultivan. Selain itu, kualitas air yang optimal juga sangat mendukung nilai kelulushidupan. Menurut Fitria (2012), tingkat kelangsungan hidup sangat dipengaruhi oleh kualitas air terutama suhu dan kandungan oksigen. Suhu merupakan salah satu faktor yang mempengaruhi pertumbuhan. Suhu dapat mempengaruhi aktifitas ikan, seperti pernafasan dan reproduksi. Suhu air sangat berkaitan dengan konsentrasi oksigen terlarut dan laju konsumsi oksigen ikan.

Tingkat kelulushidupan yang baik dipengaruhi oleh kondisi lingkungan yang optimal. Kondisi lingkungan yang baik dapat memungkinkan ikan tumbuh dengan baik. Menurut Trisnawati et al. (2014), yang dapat mempengaruhi tinggi rendahnya kelulushidupan suatu organisme adalah faktor biotik dan abiotik. Faktor biotik antara lain kompetitor, kepadatan populasi, umur dan kemampuan organisme dengan lingkungan sedangkan faktor abiotik seperti suhu, oksigen terlarut, $\mathrm{pH}$ dan kandungan ammonia.

\section{KESIMPULAN}

Kesimpulan yang dapat diambil dari hasil penelitian adalah sebagai berikut:

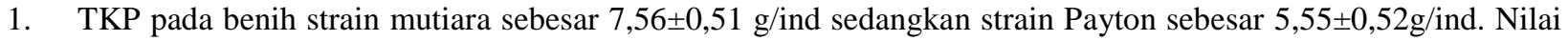
FCR yang diperoleh pada benih ikan lele strain Mutiara ialah sebesar 1,15 sedangkan pada strain Payton sebesar

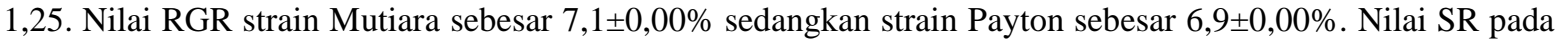

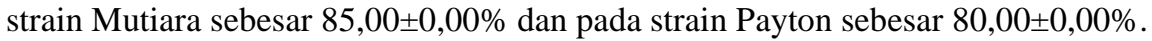

2. Produksi benih ikan lele dari strain Mutiara memiliki tingkat produksi yang lebih baik bila dibandingkan dengan strain Payton. Tingkat produksi diantaranya meiputi TKP, FCR SGR dan SR.

\section{SARAN}

Saran yang dapat diberikan pada penelitian ini adalah sebagai berikut:

1. Sebaiknya pemijahan dilakukan dalalm interval waktu yang tepat, sehingga kualitas induk tidak mengalami penurunan.

2. Sebaiknya pembudidaya lebih selektif dalam menentukan induk yang akan dipilih. Pemilihan strain mutiara merupakan solusi bagi pembudidaya untuk dapat menghasilkan benih dengan kualitas unggul.

\section{UCAPAN TERIMA KASIH}

Terimakasih kami sampaikan kepada Lembaga Penelitian dan Pengabdian Kepada Masyarakat (LPPM) Universitas Diponegoro yang telah membiayai penelitian ini melalui Program Penguatan Komoditi Unggulan Masyarakat (PKUM) sumber dana selain APBN Undip Tahun Anggaran 2018 sesuai dengan surat penugasan pelaksanaan, nomor: 475-04/UN7.P4.3/PM/2018.

\section{DAFTAR PUSTAKA}

Abidin, Z., M. Junaidi, Paryono, N. Cokrowati dan S. Yuniarti. 2015. Pertumbuhan dan Konsumsi Pakan Ikan Lele (Clarias sp.) yang Diberi Pakan Berbahan Baku Lokal. J. Depik. 4(1): 33-39.

Ahmadi, H., Iskandar., N. Kurniawati. 2012. Pemberian Probiotik dalam Pakan Terhadap Pertumbuhan Lele Sangkuriang (Clarias gariepinus) pada Pendederan II. J. Perikanan dan Kelautan. 3(4): 99-107.

Amin, M. 2007. Pengaruh Enzim Fitase dalam Pakan Terhadap Kecernaan Nutrien dan Kinerja Pertumbuhan Ikan Lele Dumbo (Clarias sp.). [Thesis]. Sekolah Pascasarjana, Institut Pertanian Bogor, Bogor, 56 hlm. 
Ardyanti, R., D.D. Nindarwi, L.A. Sari dan P.D.W. Sari. 2017. Manajemen Pembenihan Lele Mutiara (Clarias sp.) dengan Aplikasi Probiotik di Unit pelayanan Teknis Pengembangan Teknologi Perikanan Budidaya (UPT PTPB) Kepanjen, Malang, Jawa Timur. Journal of Aquaculutre and Fish Health., 7(2): 84-89.

Badan Standardisasi Nasional [BSN]. 2000. Induk Ikan Lele Dumbo (Clarias gariepinus x C. fuscus), kelas induk pokok. Standar Nasional Indonesia (SNI) 6484.1:2014, $8 \mathrm{hlm}$.

Balai Penelitian Pemuliaan Ikan [BPPI]. 2014. Petunjuk Teknis Budidaya Ikan Lele Mutiara. Balai Penelitian Pemuliaan Ikan (BPPI). Sukamandi, (52 hlm).

Begum, M., P. Noor P., Ahmed K. N., Sultana N, Hasan MR, Mohanta LC. 2014. Development of A Culture Techniques for Tubificid Worm, Under Laboratory Conditions.

Efrizal. 1998. Respon Ovulasi Ikan Lele Dumbo (Clarias gariepinus) dari Berbagai Dosis Hormon LHRH-a, Fisheriers Jurnal. Garing. 7 (2). Jurnal Fakultas Perikanan Universitas Bung Hatta. Padang.

Eyo, V.O., Ekanem, A.P., and Ajom, V.A. 2016. Fecundity Studies of the African Catfish Clarias gariepinus (Burchell, 1822) Fed Coppens Feed and Unical Aqua Feed in Circular Concrete Tanks. Journal of Coastal Life Medicine, 4(7), 531-535

Fitria, A.S. 2012. Analisis Kelulushidupan dan Pertumbuhan Benih Ikan Nila Larasati (Oreochromis niloticus) F5 D30-D70pada Berbagai Salinitas. Fakultas Perikanan dan Ilmu Kelautan, Universitas Diponegoro. J. of Aquaculture Management and Technology. 1(1): 18-34.

Fran, S. dan J. Akbar. 2013. Pengaruh Perbedaan Tingkat Protein dan Rasio Protein Pakan terhadap Pertumbuhan Ikan Sepat (Trichogaster pectoralis). Fish Scientiae. 3(5): 53-63.

Gbemisola, O.B., and Adebayo, O.T. 2014. Sperm Quality and Reproductive Performance of Male Clarias gariepinus Induced with Synthetic Hormones (Ovatide and Ovaprim). International Journal of Fisheries and Aquaculture, 6 (1), 9-15.

Ghozali, I. 2006. Aplikasi Analisis Multivariate dengan Program SPSS, Semarang: Badan Penerbit Universitas Diponegoro.

Hamron, N., Y. Johan dan B. Brata. 2018. Analisis Pertumbuhan Populasi Cacing Sutera (Tubifex sp.) sebagai Sumber Pakan Alami Ikan. NATURALIS. 7 (2) : 79-89

Hastuti, S dan Subandiyono. 2014. Performa Produksi Ikan Lele Dumbo (Clarias gariepinus) yang Dipelihara dengan Teknologi Biofloc. J. Of Fisheries Science and Technology (IJFST). 10(1): 37 - 42.

Iswanto, B., R. Suprapto, H. Marnis, dan Imron. 2015. Karakteristik Morfologis Dan Genetis Ikan Lele Afrika (Clarias gariepinus Burchell, 1822) Strain Mutiara. Jurnal Riset Akuakultur., 10(3): 325-334. ,R. Suprapto, H. Marnis dan Imron. 2017. Performa Reproduksi Ikan Lele Mutiara (Clarias gariepinus) . Media Akuakultur., 11 (1): 1-9.

Jauncey, K. 1998. Tilapia Feed and Feeding. Pisces Press. England.

Kerneta. 2014. Analisis Usaha Budidaya Ikan Lele (Clarias sp.) pada Lahan Rawa di Sumatera Selatan. Prosiding Seminar Nasional Lahan Suboptimal. Palembang. ISSN : 979-587-529-9. Hlm 309-318.

Madinawati., N. Serdiati and Yoel. 2011. Pemberian Pakan yang Berbeda Terhadap Pertumbuhan dan Kelangsungan Hidup Ikan Lele Dumbo (Clarias gariepinus). Media Litbang Sulteng IV. 2. [7].

Murtidjo, B. A. Beberapa Metode Pembenihan Ikan Air Tawar. Kanisius. Yogyakarta.

Nzeh, C. G and I. Obaroh. 2012. Ovaprim Doses Effect on Eggs of African Mudfish Clarias gariepinus. Life Science. $2(2): 5-9$.

Ngatung, J. E. , H. Pangkey dan J. F. Mokolensang. 2017. Budi daya Cacing Sutra (Tubifex sp.) dengan Sistem Air Mengalir di Balai Perikanan Budidaya Air Tawar Tatelu (BPBAT), Propinsi Sulawesi Utara. 5 (3) : 18 - 22

Omitoyin, B.O., Adesehinwa, A.O.K., and Edibite, L.I. (2005). Reproductive Performance and Serum Biochemistry Of Female Clarias gariepinus Broodstock Raised in Pond Effluent Water. Tropical and Subtropical Agroecosystem, 5, 117-122.

Rachmawati, D., I. Samidjan dan H. Setyono. 2015. Manajemen Kualitas Air Media Budidaya Ikan Lele Sangkuriang (Clarias gariepinus) dengan Tekni Probiotik pada Kolam Terpal Di Desa Vokasi Reksosari, Kecamatan Suruh, Kabupaten Semarang. Pena Akuatik Indonesia. 12(1): 24-32.

Saputra, E., F. H. Taqwa dan M. Fitrani. 2014. Kelangsungan Hidup dan Pertumbuhan Benih Nila (Oreochromis niloticus) selama Pemeliharaan dengan Padat Tebar Berbeda di Lahan Pasang Surut Telang 2 Banyuasin. J. Lahan Suboptimal, 2(2): 197-205.

Standar Nasional Indonesia. 01-4087. 2006. Pakan Buatan Untuk Ikan Lele Dumbo (Clarias gariepinus) pada Budidaya Intensif.

Stickney, R. R. 1979. Principle of Warm Aquaculture. John Willey and Sons, New York. 
Sukendi. 2007. Vitelogenesis dan Manipulasi Fertilisasi pada Ikan. Bahan Ajar Biologi Reproduksi Ikan. Fakultas Perikanan dan Ilmu Kelautan UNRI. Pekanbaru. 45 hlm

Suryadin, D., S. Helmiati dan R. Rustadi. 2017. Pengaruh Ketebalan Media Budidaya Cacing Sutera (Tubifex sp.) mengunakan Lumpur Limbah Budidaya Lele. Jurnal Perikanan Universitas Gadjah Mada. 19 (2) : 97-105.

Syaputra, S. E., H. Wijayanti dan B. Putri. 2017. Efektivitas Ampas Tebu yang Difermentasi sebagi Media Tumbuha Budidaya Cacing Sutera (Tubifex sp.). e-JRTBP. 5(2) : 597-603.

Trisnawati, Y., Suminto dan A. Sudaryono. 2014. Pengaruh Kombinasi Pakan Buatan dan Cacing Tanah (Lumbricus rubellus) terhadap Efisiensi Pemanfaatan Pakan, Pertumbuhan dan Kelulushidupan Lele Dumbo (Clarias gariepinus). J. Of Aquaculture Management And Technology. 3(2): 86-93.

Warades, E and Pindo. 20118. Media Porosity in Silk Worm Culture (Tubifex sp.). Aquasains. (2) 6: 591-596

Wulandari, C., F. A. Harahap dan T. Gulton. 2017. Pengaruh Pemberian Hormon Ovaprim dengan WOVA FH terhadap Daya Tetas Telur Induk Ikan Lele Sangkuriang di Balai Benih Ikan Kabupaten Samosir. Prosiding Seminar Nasional III Biologi dan Pembelarannya Universitas Negeri Medan. ISBN : 978-602-5097-61-4. Hlm 247-257. 